\title{
What explains differences in countries' migration policies?
}

\author{
Yasin Kerem Gümüş
}

Faculty of Management, Sakarya Universiy, Turkey

\begin{abstract}
The aim of this paper is to analyse the reasons for differences in national migration policies. European societies are struggling with the problem of how to best include the immigrants in their social structures. Although national migration policies in Europe have developed some common elements in recent years the contents and structure of national programmes vary widely in terms of their scope, goals, target groups and the institutional actors involved. The main question of the paper is "What explains the different migration policies of countries?" To answer the question, after mentioning the current differences within the European Union in terms of their migration policies, the paper will take Germany and France as examples which demonstrate sharply different cases of immigrant integration policies in the public course.
\end{abstract}

Key words: Migration Policies, Integration, Managing migration, France, Germany,

JEL Code: F22

(C) 2015 Published by SSBFNET 


\section{Introduction}

Migrations as an international issue has become a major phenomenon worldwide in recent decades. The EU has played a significant part in this issue. According to the OECD at the end of the $20^{\text {th }}$ century more than 20 million foreigners were living in the countries of the European economic area (OECD, 2001). That constitutes 5.3\% of the total population in that area, and it does not include naturalised immigrants. It also does not include undocumented immigrants or those waiting in asylum procedures or other situations. The IOM report (IOM, 2013) clearly using broader criteria, estimates the migrant stocks in the whole European continent at more than 56 million, or $7.7 \%$ of the total population.

The integration of this high number of immigrants is a challenge to the established patterns of nation building and welfare state policies. European societies are struggling with the problem of how to best include the immigrants in their social structures. In this struggle European countries apply different national programmes. While Germany will not accept immigrants as citizens but nevertheless includes them in almost all social policy measures, the French system applies a more assimilationist strategy that tries to transform a population of foreign origin into French people.

The aim of this paper is to analyze the reasons for differences in national migration policies. The main question of the paper is "What explains the different migration policies of countries?" To answer the question, after mentioning the current differences within the European Union in terms of their migration policies, the essay will take Germany and France as examples which demonstrate sharply different cases of immigrant integration policies in the public course.

\section{Differences in Migration Policies?}

Although national migration policies in Europe have developed some common elements in recent years the contents and structure of national programmes vary widely in terms of their scope, goals, target groups and the institutional actors involved. Member states differ significantly in their approaches and political priorities. This diversity mainly derives from the different historical backgrounds, societal models and patterns and traditions of migration flows (Carrera, 2006).

The European countries have different immigration experiences and backgrounds (Penninx 2004). Some European countries like Switzerland, Belgium and France have a long pre-war history of immigration which was taken up again soon after World War II. Others have built up their immigration experiences in the decades following World War II such as The United Kingdom, Sweden, Germany, Austria and the Netherlands. In other countries such as Italy, Spain, Portugal, Greece and Ireland which used to be emigration countries until recently, the immigration experience builds on a period of just one decade or so. It is clear that the migration differences are determined by the size of the immigrant population. Also these migration movements have a variety of backgrounds and forms. (Penninx, 2004). On one hand, uneven development and political instability, combined with the intensity and reach of new communication media and the density of transport facilities have generated greater migration pressures and supply driven migration movements. On the other hand, economic and demographic developments in Europe itself have given rise to new demand driven movements towards some countries. 
It can be said that policies relating to immigration within the EU area are mainly uneven (Penninx, 2004). On the one hand the EU created a sort of fundamental right to migrate within the EU area for citizens of member states and moreover, more or less lenient policies practised in all states for highly skilled and company-linked migrants from outside of the EU. On the other hand the EU member states have developed separately restrictive and defensive, but largely ineffective, immigration policies to keep out all other unasked for migrants.

Although national migration policies in Europe in the legal and political domain have developed more common elements in recent years, quite significant differences remain. In additionl to historical backgrounds such differences are related to basic ideas about membership of the political community in different countries (Penninx, 2004).

Germany, for example, has always maintained that 'it is not an immigration nation' (Hammar 1985). The admission of foreigners was always closely tied to labour markets needs and when those needs were met, workers were excluded or expelled (Hammar 1985). It is because Germany defines its national community in terms of ethnicity and therefore welcomes re-settlers (Aussiedler) as Germans returning to the fatherland, but regards settled foreigners as Ausländer, an "alien element".

In terms of official policies, another difference within policies in Europe exists between multiculturalists, assimilationist and exclusionist definitions (Carrera, 2006). The basic premise of multiculturalism is that immigrants cannot become equal citizens unless state and society accept both individuals and groups have the right to cultural differences. According to multiculturalists, the prevailing institutions and rules in society are historical and cultural products that are not neutral for newcomers and therefore may need revision in order to accommodate newcomers. The UK, Dutch and Swedish policies in the 1980s and early 1990s have presented themselves as multiculturalist policies. In assimilationist policies in contradiction, newcomers are supposed to adapt at least to the public institutions of that society. This may lead to strong assimilation pressure. French policies can be given as an example of assimilationist policies. The Exclusionist model is characterised by restrictive and rigid immigration legislation and policies. It consists of policies aimed at artificially maintaining the temporary character of immigrant settlement. Germany, Austria and Belgium can be given as an example of this kind of policy.

\section{Integration Policies of Germany and France}

Integration can be described as an acquisition of rights, access to positions and statuses, a change in individual characteristics, a building of social relations and a formation of foreigners of belonging and identification by immigrants towards the immigration society. It is dependent on a number of conditions on the part of the receiving society which could generally be described as its openness to the new group of people (Heckmann 1999).

Within the EU, the content and structure of integration programmes differ widely in terms of their scope, goals, target groups and the institutional actors involved. Member states differ significantly in their approaches and political priorities vis-à-vis the integration of migrants (Carrera, 2006). According to Heckmann, these differences derive from different historical backgrounds, societal definitions of immigration, social order and sense of nationhood (Heckmann, 
1999). In his article, Heckmann analyses integration policies in Germany and France which he thinks stand for sharply different cases of immigrant integration policies in the public course. In this part the differences in integration policies of Germany and France will be analyzed.

\subsection{Integration programme in Germany}

As to the societal definition of the immigrant situation in Germany the most often heard phrase is "Deutschland ist kein Einwanderungsland" and this is thought to be a highly specific characterisation of the German situation.

Historical-structural theory, rooted in neo-Marxist political economy, emphasizes how economic and political power are unequally distributed, cultural beliefs and social practices tend to produce structural inequalities. Migration provides a cheap labour force in 'receiving areas' with a corresponding decline of skills in origin areas (Castles, et al 2014).

Inflows of non-German immigrants began in the second half of the 1950s in response to a labour shortage and economic recovery. Germany signed a series of bilateral recruitment agreements for the recruitment of unskilled Gastarbeiter (Guest workers) in the industrial sector. The Rotation Principle introduced requiring male migrants return home after 1-2 years to discourage permanent settlement. A ban on recruitment of foreign workers was introduced in the economic recession of 1973 reinforcing the idea that migration is a way of providing a cheap temporary exploitable labour force (Ozcan, 2004).

Denial of the immigration situation was officially maintained by the federal government until 1998. Since 2000 a series of legal reforms aimed at integrating non-nationals and promoting harmonious community relations have been introduced acknowledging that Germany is now a country of immigration. A 2005 census suggested that just under one fifth of the overall population was of immigrant origin (Sussmuth, 2009)

In the 1980s and 1990s non-statutory welfare agencies implemented a de facto reform of integration policy and practice bottom-up from the local level. The delegation of public responsibilities to non-statutory welfare agencies is a specific feature of German migration policy. In terms of social order, Soziale Marktwirtschaft as a system of economic, social and political relations is a basic element of the social order in Germany. The role of the state is understood in that system in an interventionist sense i.e. to help provide social security, social justice and to improve opportunities for disadvantaged groups. The most important aspect of the welfare system for immigrant integration is that non-citizens are generally included in it (Heckmann 1999). Six agencies (Catholic CARITAS, Protestant Diakonie, Jewish ZWST, the labour movement's AWO, the non-partisan umbrella organisation DPWV and the German Red Cross) implement the overwhelming majority of services to migrants and integration measures with public funds from the EU and government at national, state, district and local levels. The drawback with this system is the lack of coordination and exchange of information between the various bodies at local and regional level (Borkert et al 2007).

In the period 1988-2003, after reunification, 3 million ethnic Germans returned to Germany, almost 2.2 million from the former Soviet Union. As a result of these inflows from the 1990s the Government began to take measures to 
moderate returns giving aid to ethnic German communities in their countries of origin to stem the flow and established a quota system. These 'Aussiedler' enjoyed certain privileges to foster their integration into society and the labour market such as assistance with language training, employment and welfare but still face severe problems with social and economic integration largely through a poor knowledge of German. Nevertheless they are viewed as primarily German and not foreigners which is reflected in the reporting of statistics (Ozcan, 2004).

In terms of the sense of nationhood, the traditional concept in Germany since the $19^{\text {th }}$ century has been an ethnic nation. Since nation defines itself as a community of descent with a common culture and history belonging to the people and legal membership in the political community, that is citizenship, are closely connected to one another. One of the consequences of this principle is that the inclusion into a nation that understands itself as a community of descent and culture of non-nationals is difficult or defined as an exception to the rule (Heckmann, 1999).

German integration policy has recently opened the core institutions to immigrants including them in the general welfare state and social policy system but the effects of welfare state inclusion have been somewhat undermined by a lack of legal integration due to a restrictive naturalisation programme. Welfare state integration without citizenship makes integration policy ambivalent. In 2000 a new law on citizenship including the jus soli concept for children of foreigners born in Germany introduced the concept of naturalisation as an important step bringing the integration process into official policy (Borkert et al 2009).

In terms of the educational system, the federal states are the main actors in educational policy. Coordinated efforts on the national level are regularly undertaken by the Kultursministerkonferenz. The conference of ministers for culture in 1976 took basic decisions for the educational policy toward the migrants' children. One major decision was that the children of the 'guestworkers' were obliged to attend school. According to the 1976 decisions the children of 'guestworkers' should be integrated into the regular school system. Preparatory and parallel German language training should be given to them. The understanding of these decisions was to avoid social problems with a population that would temporarily live in Germany (Heckmann, 1999).

Nevertheless, foreign children continue to be less successful in school than their German peers. Nearly three times as many are enrolled in Hauptschulen, the lowest tier in German's multi-track school system and less than half of them attend Gymnasien, the highest tier which qualifies pupils for university entrance. More than twice as many foreign youths drop out of school before finishing. Since OECD PISA reporting began in 2009 the group of young people of immigrant background has shown improvement but still lags far behind that of native Germans (Federal Government, 2014)

While Germany has been moving towards a functionalist approach in which a tendency towards equilibrium exists and migration is treated as a positive phenomenon serving the interests of most people and contributing to greater equality within and between societies, some shadow of historical attitudes still remain. Professor Dr Süssmuth concludes 'The system must...make Germany a country of destination attractive to the most talented and choosiest labour migrants who belong to the so-called creative class.' (Süssmuth 2009) while the Federal Government asserts '...integration 
policy is based on the principle of offering more support for integration efforts while making requirements stricter. Immigrants are required to learn German, through their own efforts and with government help, and to know and respect the basic values of our society' (Federal Government, 2014).

Germany has set an example in the area of relocating refugees. In 2013 the German State pledged 5,000 places for refugees fleeing the conflict in Syria, the UNHCR acknowledging that this represented 'the biggest relocation programme in existence... But the UN also notes that resettled persons in Germany have fewer rights in terms of family reunification which may inhibit the integration of the refugees and Palestinians have not been integrated into their resettlement programmes for Iraqi refugees indicating that the German government continues to be choosey about which immigrants they are prepared to accept.

\subsection{Integration programme in France}

France has a century long tradition of de facto immigration and integration. In the period before 1945 the number of foreigners increased rapidly from 381,000 in 1851 (1.1 percent of the total population) to 1 million ( 2.7 percent) in 1881, rising to 1.2 million ( 3 percent) in 1911. The majority of the inflow came from neighbouring countries and were mainly men providing unskilled labour to agriculture, mines and steelworks.

In France falling birth rates after 1860 led to a shortage of labour during dustrialization accompanied by relatively low rural to urban movement. Smaller families were encouraged due to the influence of Malthus driven by the desire to pass on property to the next generation intact and allow sufficient resources for education. In Ireland a similar situation led to large-scale emigration but in the same period in France emigration was relatively low. The only exception was the settlement of Algeria after 1830 following a French invasion of North Africa. The shift from small to large scale enterprises could only be achieved through foreign labour so immigration played an important part in the emergence of modern industry (Castles et al 2014).

In addition, the Nationality law of 1889 was designed to turn immigrants and their sons into conscripts to supply the army in the impending war with Prussia. From the mid- $19^{\text {th }}$ century onwards until the present day the labour market in France has been regularly supplied with foreign workers who make up on average 10-15 percent of the working class.

France was the only Western European country in the interwar years to experience substantial immigration but there was no return to the free movement policy of the pre-war years. Government and employers refined systems established during the war. Recruitment agreements were made with Poland, Italy and Czechosovakia to supply farming and mining interests. At the same time North African migration to France was developing. A 1914 law had removed barriers to the movement of Algerian Muslims to France although they remained non-citizens. A policy of discrimination in favour of French workers saw the introduction of maximum quotas in 1932 when many migrants were sacked or deported (Castles et al 2014).

After World War II the Office National d'Immigration (ONI) was established to organize recruitment from Southern Europe. Migration was seen as a solution to postwar labour shortages. Low birth rates and war losses meant family 
settlement was now envisaged. By 1970 two million foreign workers were resident in France. By 1968 ONI statistics revealed that 82 percent of these came as 'clandestines'(Castles et al 2014).

As to the societal definition of the immigration situation France never understood herself - like the United States - as a country or nation of immigrants. Even as late as the 1960s and 1970s, the large recruitment of foreign workers "was viewed and often felt as work immigration limited in time" in French territory and society (Heckmann, 1999).

The French have always been reticent about the use of ethnic categories. Republican ideology is based on principles of civic citizenship and equal individual rights for all. The recognition of cultural difference or ethnic communities in unacceptable. In terms of a sense of nationhood, the French concept of nation is built upon the political principles of the French Revolution and "National integration as a whole is political: members of the national society are being integrated by individual citizenship, following a univeralist view of the citizen. This principle, stemming from the founding myth of the French Revolution is the ideological foundation of the so-called 'assimilation' policy. It is by individual citizenship that this policy tries to transform a population of foreign origin into French people (Schnapper et al 1998).

Consequently despite being a country of immigration since the $19^{\text {th }}$ century France does not have any specific integration policies. The French operate on the implicit principle that a lack of specific integration policy is the best method of long-term integration. All French citizens are regarded as French regardless of their country of origin (Borkert et al 2009).

In terms of citizenship policies which is the basis for general integration in state and society Nationality laws in France have been very open since 1889. Traditionally, ius sanguinis and ius soli combine so that anyone born in France who wants to become French - even from foreign parents in an illegal status - can become French. What is specific about the French model of ius soli is that it founds nationality on socialization and not on ethnic origin. Thus it is also different from the American case which might be called a simple ius soli model (Schnapper et al 1998).

In terms of Social Order France is a centralized modern welfare state with an étatist tradition that is the state takes an active role in society. France is a welfare state for both citizens and resident (legal) foreigners. If immigrants are still foreigners they are entitled to the same social rights as French people (Heckmann, 1999).

Multiculturalism is confined to the private sphere and not recognised in the public domain. Ethnic divisions are not taken into account in either school or the workplace. This 'colour-blind- policy is intended to favour integration and promote a strict policy of equal opportunity. Borkert et al (2009) point out that the French model stems from the fact that historically France is made up of various regions with their own cultural and religious identities, traditional dress codes and languages. These were transformed into French society by the intervention of a centralist state which did not promote regional identity. 
In terms of schooling, the school has become the core institution for the integration of immigrants and their children. "The school may be considered as the main instrument and the symbol of the French model of integration: l'ecole republicaine was supposed to create a cohesive French nation" (Schnapper et al 1998). "Based on the principle of centralization, educational programs are... the same in the 36000 French cities and villages. In this conception, school is to provide apprenticeship of French language, of calculus, of rights and duties of citizenship. But is also seen as the very place of socialization to French culture and of social advancement" (Schnapper et al 1998).

The school system embodies equality and secularism epitomised by the affaire des foulards regarding the wearing of headscarves by Muslim girls undermining the principle of universal values yet special measures have been introduced to assist immigrant children to enter the mainstream as soon as possible and affirmative action (discrimination positive) is implicit in urban planning policy which focuses on certain districts but is based on socio-economic rather than ethnic criteria. Nevertheless this has implications for the integration of migrants as they often represent more than 40 percent of the residents of these areas. No form of discrimination in the workplace is permitted with the only exception being made for officers in the civil service who have to be French citizens (Borket et al 2009).

Despite its emphasis on assimilation and universality, the French model has not been more successful than other approaches in eradicating xenophobia, racism and discrimination. The reality is that people of non-European birth and parentage face social exclusion and discrimination. Protest has been concentrated in les banlieues, outer city suburbs with a high concentration of immigrants. Here low-status employment, insecurity, high unemployment rates especially for young workers where 43 percent of young men in 2010 were jobless led to protracted rioting in 2005 and 2007. Protestors pointed to the use of racial profiling by the police, racial discrimination, discrimination in the job market, the absence of upward social mobility, poverty accompanied by petty crime and delinquency, isolation in the form of a lack of public transport and the development of a male-oriented urban culture leading to a sense of territorial appropriation by rival gangs seeking to defend their territory from outsiders as primary causes of the outbreak of violence. The riots had no religious connotation. Castles Haas and Miller note that "Ironically, the violent protests of the largely immigrant-background youths constituted classically French political participation and mainly involved French citizens (Castles et al 2014).

\section{What explains the different migration policies of countries?}

Functionalist theory suggests that some countries adopt a positive attitude towards migration particularly when migration is needed to boost the workforce in periods of industrialization for following wars with the resultant shortage of manpower or when particular skills are needed (for example the shortage of skilled medical personnel in state health systems) but even when immigration is seen as a practical requirement it has been viewed largely as a temporary solution with governments restricting access to citizenship, family reunion and voting rights and, in the case of Germany, actively promoting return migration at the end of a specific period of employment.

Neoclassical theory sees migration as a function of geographical differences in supply and demand for labour that encourages workers to move from low-wage, labour surplus regions to high-wage labour-scarce regions increasing 
'human capital' in the receiving countries, enhancing the pool of specific knowledge and skills (Sjaastad 1962 cited in Castle et al 2014).

Historical-structural theory suggests accounts for differences according to varying historical backgrounds. This point of view forms the basis of globalization theory which emerged in the 1990s. In which a key indicator is the rapid increase in cross-border flows of capital, technology, services and personnel characterized by foreign direct investment (FDI), liberalization and deregulation (Petras and Veltmayer 2000; Castle et al 2014).

The EU Migrant Integration Policy Index (MIPEX) provides a useful assessment tool for comparison of differences in migration policies between countries. MIPEX uses 148 policy indicators to benchmark current laws and policies in consultation with scholars and institutions using and conducting comparative research. MIPEX regularly monitors 40 countries across the globe extending their influence well beyond Europe.

MIPEX suggests that German policies have improved little in the past three years. Germany sits currently $13^{\text {th }}$ in the index with a score of 57 points, scoring average for Europe on education and family reunion policies but far below on matters of equality and long-term residence conditions.

Table 1. Positive and Negative Aspects of German Integration Policy

\begin{tabular}{|c|c|}
\hline \multirow{5}{*}{ Positive Aspects } & Most professional citizenship test but language levels may be too high to pass \\
\hline & Clear path to citizenship like major countries of immigration \\
\hline & $\begin{array}{l}\text { Some of best targeted measures for labour market integration except in recognising } \\
\text { qualifications }\end{array}$ \\
\hline & Secure residence and equal rights for families as in Northern Europe \\
\hline & $\begin{array}{l}\text { Foreigners have some political opportunities at local/regional level but not in elections } \\
\text { or national politics }\end{array}$ \\
\hline \multirow{4}{*}{ Negative aspects } & Average education policies - more ad hoc funding projects than entitlements in länder \\
\hline & $\begin{array}{l}\text { Discrimination law undermined by weak equality bodies/commitments - most countries } \\
\text { give better help to potential victims }\end{array}$ \\
\hline & German tests abroad for spouses may facilitate or discourage integration in Germany \\
\hline & Most restrictive conditions for long-term residence in Europe and North America \\
\hline
\end{tabular}

Source: MIPEX key findings www.mipex.eu/germany Data from 1 November 2013

The same organization's country report on France indicates that despite having an opposing ideological approach to migration in their index of countries. France occupies 16th position in the table, in other words much the same position as Germany, with a slightly lower score of 51. MIPEX is critical of France complaining that 'newcomers 
encounter the least favourable and most contradictory integration policies of all major countries of immigration - more measures focus on unemployed migrants while keeping millions of jobs closed' (MIPEX/France, 2014) .

Table 2. Positive and Negative Aspects of French Integration Policy

\begin{tabular}{|l|l|}
\hline \multirow{5}{*}{ Positive aspects } & $\begin{array}{l}\text { 2007 Hortefeux law introduced minor changes including new integration courses for } \\
\text { families abroad }\end{array}$ \\
\cline { 1 - 2 } $\begin{array}{l}\text { French naturalisation shares basics with other countries of immigration but excessive } \\
\text { discretion }\end{array}$ & $\begin{array}{l}\text { Pre-departure courses abroad still not as cost-effective as the Integration Contract in } \\
\text { country (but still more favourable than German or Dutch models) }\end{array}$ \\
\hline \multirow{2}{*}{ Negative aspects } & $\begin{array}{l}\text { France leads on anti-discrimination, if nationality discrimination and equality body is } \\
\text { not undermined }\end{array}$ \\
\hline & $\begin{array}{l}\text { Few countries follow France in imposing job, language and integration requirements } \\
\text { for family reiunions }\end{array}$ \\
\cline { 2 - 3 } & $\begin{array}{l}\text { New targeted labour market measures still overlook major problems of access } \\
\text { Targeted education measures for migrant children still weak, in pilot phase. }\end{array}$ \\
\hline & $\begin{array}{l}\text { Most countries that facilitate naturalisation grant local voting rights for foreigners, not } \\
\text { yet in France. }\end{array}$ \\
\hline
\end{tabular}

Source: MIPEX key findings www.mipex.eu/germany Data from 1 November 2013

MIPEX notes that some obstacles have been removed for work but added for family reunions. Migrants are encouraged to become citizens but not yet given the right to vote as foreigners despite public support for this and express the fear that government action may undermine the strong existing anti-discrimination law and equality body.

Thus we see that although one is defined as exclusionist and the other as assimilationist in practice Germany and France, both constrained by European standards, produce much the same results in the practical application of their migration integration policies. In Spain also European standards and co-operation have been used to settle migrants' residence and family equality issues so it appears that where an over-arching body does exist this can have a significant effect in reducing the differentials between national migration programmes. Germany has had to accept that it is now a country of immigration and adopt plans for permanent settlement and naturalisation of its immigrant 
communities while France has had to introduce exemptions to its universalistic policies to accommodate the needs of its newcomers.

When considering the factors that explain the different migration policies of countries it is important to note that during historic periods of high trade and international movement, such as during the latter part of the nineteenth century, countries generally had no major migration policies or restrictions (Williamson 1996). It is only relatively recently that controls and policies have been used to reduce the cross border movement of people. The growth in border controls is particularly strong in the area of migration where countries use visas and work permits to control long term economic and social migrants, restricting their movements and reducing the volume of people moving permanently across borders (Ng and Whalley, 2008).

The main reason for the emergence of these policies is that previously high costs of travel and slow communication systems tended to create natural barriers to migration. New technologies have been developed to reduce these barriers and so countries have begun to perceive migration has a threat to their sovereignty. This has led to the use of immigration policy as a method of exercising national sovereignty (Freeman, 2006). As such, one of the key reasons for different migration policies across countries is the extent to which the local populace feels its sovereignty may be threatened by migration levels and the extent to which this is a political concern.

Whilst the politically motivated factors that drive differences in migration policy also influence other policies such as trade, environmental and finance policies, it is interesting to note that differences in migration policies across countries tend to be much more marked than those in other areas. This is because, unlike most other policies with global impacts, there is no coherent global institutional framework for managing international migration policy (Betts, 2011). Whilst trade, finance and the environment are handled by various bodies such as the WTO, IMF and UN, there is no overarching international migration organisation. Whilst some international organisations focus on certain areas of migration such as human trafficking and certain regional organisations such as the EU impose consistent internal migration policies, individual nations retain power over their own migration policies. As such, migration policies around the world are not based on a single framework but are rather influenced by national laws, various legal instruments, a range of nonbinding agreements and negotiated policy understandings (Betts, 2011). With such a diverse range of factors influencing migration policies for every nation, the question is thus not why migration policies are different across nations but rather why one would expect them to be the same.

This is particularly the case given that all countries in the World, be they net senders or net receivers of migrants, have the power to set migration quotas and control migration. In such a situation, the nature of migration across countries is not only determined by the individual migration policies of a given country, but also by bilateral agreements said country agrees with its international peers in order to facilitate or control migration between the two countries. According to Stark et al (2012) "in equilibrium both the sending country and the receiving country can participate in setting the migration policy, that bilateral agreements can arise as a welfare-improving mechanism, and that the 
sending country can gain from migration even when it does not set its preferred policy". This implies that not only are national migration policies strongly influenced by national factors, but also by the bilateral negotiation process between nations. As such, it is logical to assume that each pair of nations will achieve a different set of migration policies based on their specific circumstances relative to each other.

In addition to the political and institutional factors discussed above, it is also important to consider the labour and economic impact of migration as a driver of policy differences. In particular the international movement of labour is substituted for by the international movement of goods or factors of production (Feenstra, 1998; Freeman, 2006). In other words, rather than allowing migration, countries can simply outsource their productive capacity to other nations where labour costs are lower and gain similar productive benefits whilst maintaining sovereignty. This is particularly the case where import tariffs are low, and thus the outsourcing of production is simple. However, it is important to note that immigration policies can restrict the ability of domestic producers to compete with labour abundant nations when exporting (Collins et al 1997). As such, immigration policies across nations can be influenced by local levels of economic competitiveness and the need to allow immigration to boost said competitiveness, or by the desire to restrict immigration in order to prevent immigrants dominating the workforce due to their lower labour costs. Another critical factor in this area is the fact that the high income economies have increasingly segmented labour markets. In said markets, certain sectors of the labour market, usually those where the work is dirty dangerous and/or difficult are eschewed by domestic workers due to their low status and lack of security. As such, these sectors can become dominated by migrant workers (Koser, 2010a). The migration policy of a given nation can thus also be influenced by this nation's need for labour in this sector of the economy, which implies that social factors may also influence migration policies.

The final factor that can influence formal migration policies is the social response to irregular migration, which is migration that occurs outside the policy framework. This is an increasing source of social concern with Koser (2010b) noting that around 2,000 migrants each year die trying to migrate from Africa to Europe across the Mediterranean, and around 600 also die trying to reach the United States from Mexico. Even if these people reach their destination they are often exploited by employers with few rights. As such, there is growing pressure on countries to design migration policies to prevent or reduce these levels of irregular migration and bring the migrants into the policy framework, particularly in light of recent analysis of irregular migration as being akin to the slave trade (O'Connell and Davidson, 2010).

\section{Conclusion}

As can be seen clearly from recent reports of OECD and IOM, more than 20 million foreigners were living in the countries of the European economic area at the end of the $20^{\text {th }}$ century. This high number of migrants is a challenge for European welfare and established patterns of nation building. In their struggle, the contents and structure of national programmes of European countries vary widely in terms of their scope, goals, target groups and the institutional actors involved. While French policies are described as assimilationist which means that newcomers are supposed to adapt at least to the public institutions of that society, German policies are regarded as exclusionist which 
is characterised by restrictive and rigid immigration legislation and policies. According to Carrera this diversity can be explained by different historical backgrounds, societal models and patterns and traditions of migration flows (Carrera 2006). These differences can be seen in their integration policies related to their different historical backgrounds, social order and sense of nationhood (Heckmann 1999).

Immigration can have untended consequences which have a significant impact on nation states especially democracies where citizenship also affect voting rights. Where migrant links form transnational communities cross-border loyalties may be seen as a potential threat to national identity and security.

Migration affects simultaneously the social transformation of the country of origin and that of destination. It can inhibit the country of origin from pursuing political and economic reform while destination countries can increase the development potential of migration by creating legal channels and integration policies that favour socio-economic mobility of migrants and prevent marginalization. New technology has played a significant part in increasing the mobility of an international workforce but at the same time it has also provided the opportunity for the development of skills and enterprise in countries of origin through outsourcing. The volume of migration has also encouraged destination countries to invest in countries of origin to stem the flow of migrants, as in the case of the German policy of assisting Aussiedler communities in their own countries rather than offering them places in Germany and the flow of foreign aid to 'Third World' countries may be seen partly in this light.

Cultural and historical affiliations therefore affect attitudes to migrants from different parts of the world and encourage selectivity in receiving areas. Differentiated migration regimes as in the EU encourage mobility in the highly skilled while often denying rights to asylum seekers and refugees. Initially, while migration is sometimes welcomed as a means of supplying a labour shortage, migrants are often only offered temporary worker status and face restrictions on settlement and citizenship/voting rights.

Castles et al (2014) suggest that control of migration and differential treatment of certain categories of migrant have become the basis of a new type of transnational class structure and as long as labour demand persists such immigration regimes will continue to lead to an increase in irregular inflows and consequent vulnerability of migrants to exploitation through human trafficking and in the labour market.

\section{References}

Betts, A (2011). Global Migration Governance. Oxford. Oxford University Press.

Borkert, M , Bosswick, W , Heckmann F \& Luken-Klassen, D (2007). Local Integration policies for migrants in Europe - country reports for Germany and France. European Forum for Migration Studies Bamberg, Germany/European Foundation for the Improvement of Living and Working Conditions.

Carrera, S (2006). A comparison of Integration programmes in the EU. Trends and Weakness. Challenge Papers, No 1/March 2006. 
Castles, S, De Haas, H, \& Miller, M J (2014). The Age of Migration: International Popular Movements in the Modern World . Palgrave Macmillan, London.

Collings, W, O'Rourke, K \& Williamson, J (1997). Were Trade and Factor Mobility Substitutes in History? NBER Working Paper 6059. Cambridge MA: National Bureau of Economic Research.

European Union Database (2014). Population data. http://epp.eurostat.ec. europa.eu/portal/page/portal/population/data/database, accessed 20 June 2014.

Federal Ministry of the Interior (2014). Migration and Integration Report. www.bmi. bund.de/SharedDocs/Downloads/EN/Broschuren/migration_und_integration_en.html, accessed 26 June 2014.

Feenstra, R (1998). Integration of Trade and Disintegration of Production in the Global Economy. Journal of Economic Perspectives, 12: 31-50.

Freeman, R (2006). People Flows in Globalization. Journal of Economic Perspectives, 20: 145-70.

Hammar, T, (1985). European Immigration Policy: A Comparative Study Cambridge. Cambridge University Press.

Heckmann, F (1999). Integration Policies in Europe: National Differences and/or Convergence?. EFFNATIS Working Paper No: 28, Germany.

Koser, K (2010a). Introduction: International Migration and Global Governance. Global Governance, 16 (3):301-315.

Koser K (2010b). Dimensions and Dynamics of Irregular Migration. Population, Space and Place 16: 181193.

European Union Migrant Integration Policy Index (2013). Country reports for Germany and France. http://www.mipex.eu/germany http://www.mipex.eu/france, accessed on 14 July 2014.

Ng, E \& Whalley, J (2008). Visas and Work Permits: Possible Global Negotiating Initiatives. Review of International Organization, 3, 259-85.

O'Connell D J (2010). New Slavery, Old Binaries: Human Trafficking and the Border of Freedom, Global Networks 10(2): 244-261.

Ozcan, V (2004). Germany: Immigration in Transition. http://www.migrationpolicy.org/article/germanyimmigration-transition, accessed on 17 June 2014.

Penninx, R (2004). Integration of Migrants: Economic, Social, Cultural and Political Dimensions. European Population Forum. 
Perrin, D \& McNamara, F (2013). Refugee Resettlement in the EU: Between Shared Standards and Diversity in Legal and Policy Frames. Robert Schumann Centre for Advanced Studies, European University Institute, Florence, Italy/KNOWSET 2013/03.

Poot, J \& Strutt, A (2010). International Trade Agreements and International Migration World Econom., 33(12):1923-1954.

Schnapper, D, Peignard, E \& Krief, P (1998). Historical Foundations and present French Immigration and Integration Policy. EFFNATIS Working Paper 16, Paris-Bamberg.

Schneider, J (2012). The Organisation of Asylum and Migration Policies in Germany: Study of the German National Contact Point for the European Migration Network Working Paper 25 European Migration Network $(\mathrm{EMN}) /$ German Federal Office for Migration and Refugees.

Stark, O, Casarico, A, Devillanova, C \& Uebelmesser, S (2012). On the formation of international migration policies when no country has an exclusive policy-setting say. Regional Science and Urgan Economics, 42 (3):420429.

Süssmuth, R (2009). The Future of Migration and Integration Policy in Germany Transatlantic Council on Migration. Migration Policy Institute (MPI).

Williamson, J (1996). Globalization, Convergence and History. Journal of Economic History 56: 277-306. 